\title{
Editorial: Royal and Ancient
}

Little research would be needed to show what fortunes of war or lapses of editorial arithmetic have caused this 200th issue of a quarterly journal to appear in the middle of Volume 52 and not at the end of Volume 50 , but we have recently celebrated 50 years and 50 volumes and are not ready for 'any new nostalgias. That this lassitude may amount to an unseasonable disloyalty is suggested by an implicit rebuke from one of the pupils of a Junior Modern School in Peckham:

As 1977 is Jubilee Year my class are doing work on Royal Societies and Institutes. I would be very grateful if you could send me information. Firstly I would like to know about the aims and work of the Institute and any special activities to celebrate the Queen's Jubilee. Secondly can you tell me some of the history of the Institute, when how and where it was granted Royal Patronage and do you have a special badge or crest. Thirdly can you tell me who is allowed to join your Institute and are there special conditions of membership. Thank you for your help.

The phrase 'Royal Patronage' has a musical sound which comes partly from the earliest of its several senses. Members of the Institute and subscribers to Philosophy have just been reminded by subscription increases of the needs and problems of this and other learned societies in a time of sharp inflation. The cry for patronage in the oldest and most concrete sense is the loudest note in $A$ Survey of Learned Societies conducted and published last year by a Joint Committee of the Royal Society and the British Academy. The same report provides evidence-and we in Gordon Square can confirm from our grateful knowledge as beneficiaries in several recent years-that the sponsoring Society and Academy, with support from Government funds, are already giving some of the help that is needed.

Yet the main result of the enquiry is to show how much still needs to be done in the way of help and self-help. The talk is all of doubling subscriptions, of reducing the frequency of meetings and publications, of cheaper methods of production, and even-in circles where gloom or a sense of adventure is exceptionally deep or high-of cooperation, amalgamation or liquidation.

We remain optimistic, and not only because the word 'philosophical' also has an antique sense that has to do with calm and comfort. The support of our members and subscribers and other benefactors throughout 52 years and 200 issues inspires confidence that these figures are steps on the way to being Ancient as well as Royal. 